\title{
Needs Analysis of the Multidisciplinary Literacy Lecture Modelwith Team Teaching and an Integrative Approach
}

\author{
Wahyu Sukartiningsih ${ }^{1, *}$ Neni Mariana ${ }^{1,}$ Roihana Waliyyul Mursyidah ${ }^{1}$
}

\author{
${ }^{l}$ Universitas Negeri Surabaya \\ *Corresponding author. Email: wahyusukartiningsih@unesa.ac.id
}

\begin{abstract}
The purpose of this study is to (1) explain the need for a Multidisciplinary Literacy lecture model with Team Teaching and an Integrative Approach in terms of the profile of PGSD student graduates; (2) describe the need for a Multidisciplinary Literacy lecture model with Team Teaching and an Integrative Approach from the perspective of PGSD students' opinions, and (3) describe the analysis of constraints on the needs of the Multidisciplinary Literacy lecture model with Team Teaching and an Integrative Approach? This research is a survey of needs and constraints analysis of the Multidisciplinary Literacy lecture model with Team Teaching and an Integrative Approach. The need and content analysis of the Multidisciplinary Literacy lecture model with Team Teaching and an Integrative Approach conducted surveys, interviews, and analysis of constraints reflected in the problems lecturers face in team teaching- shaped learning. The needs and constraints analysis survey data was collected using questionnaires and interview guidelines. The population of this study were students of the PGSD Department of FIP Unesa who in the odd semester of 2021 were in semester five which consisted of 6 classes, using a random sample of 2 classes, totalling 67 students. From the results of this study, conclusions can be conveyed (1) The Multidisciplinary Literacy Lecture Model with Team Teaching and an Integrative Approach in terms of the profile of PGSD student graduates is needed because it provides a comprehensive understanding of students because they are taught by lecturers in different fields of expertise who work together at the time of the lecture; (2) The Multidisciplinary Literacy Lecture Model with Team Teaching and an Integrative Approach from the perspective of PGSD students' opinions is very much needed so that students can have a thematic learning model in SD which consists of several subjects and is united in a theme; and (3) The Multidisciplinary Literacy Lecture Model with Team Teaching and an Integrative Approach from the point of view of the PGSD lecturers' opinion is important to design because the lecturers will provide material and assist students in designing thematic learning for elementary school which includes combining several subjects that are united in a theme.
\end{abstract}

Keywords: Needs Analysis, Multidisciplinary Literacy Lecture Model, Team Teaching, Integrative Approach.

\section{INTRODUCTION}

Based on the 2013 Curriculum [1], which has been implemented in Indonesia since 2013, the Department of Elementary School Teacher Education (PGSD), as an institution that produces primary school teachers, needs to adapt to the needs in the field. Learning is no longer presented in the form of a segmented subject but is presented in integrated learning. Integrated learning is learning that is integrated from 3 or more subjects in an integrated manner. [2] says, "webbed curriculum represents the thematic approach to integrating subject matter. Typically, this thematic approach to curriculum development begins with a theme".

The 2013 curriculum also hints at the importance of multidisciplinary literacy for prospective elementary school teachers who will become classroom teachers.
Class teachers must master various scientific fields, both for main subjects and supporting subjects. Lectures conducted at PGSD are expected to be an example for PGSD students when designing learning for elementary school. Lectures carried out at PGSD so far are generally taught by PGSD lecturers who are scheduled individually according to their respective scientific fields. Likewise, the courses contained in the curriculum are generally segmented courses from one particular field or scientific clump. For example, in the Indonesian language scientific family, there are courses in Language Studies, Improving Indonesian Language Skills, etc., generally taught by a lecturer from the Indonesian language expertise field. The same applies to the clusters of Science, Mathematics, Social Sciences, PKN, Arts, and others. Lectures like this do not provide an example for students if they are not balanced with 
lectures whose nuances are similar to those carried out by classroom teachers in elementary schools who use thematic learning. With no model in the lectures conducted at PGSD, prospective teachers and teachers do not get exposure to learning that combines various scientific fields.

For this reason, multidisciplinary MKs are needed that are literate with related scientific fields in an integrated manner, such as MK Thematic Learning in the Early Grades of Elementary School, Thematic Learning in Elementary High Schools, STEM and Learning in Elementary Schools, MK Ethnopedagogy and Its Implications in Thematic Learning in Elementary Schools. Balanced Literacy, and so on. With a multidisciplinary literacy model, one MK needs to be taught by several lecturers (team teaching).

Research [2] proves that team teaching lectures can provide a comprehensive experience because the lecturer team contributes according to their respective fields of expertise. However, this research has not yet reached an attempt to design a multidisciplinary literacy lecture model [3], [4]. For this reason, it is necessary to carry out a needs analysis in multidisciplinary literacy lectures with Team Teaching and an integrative approach [1]

This lecture is the first stage in research that aims to produce a model of Multidisciplinary Literacy lectures with Team Teaching and an Integrative Approach [5], [6]. At the initial stage, researchers need to conduct a needs analysis to generate data from survey results and exploration the needs of this course. The needs analysis is important to do to obtain data about the need to develop a model of Multidisciplinary Literacy lectures with Team Teaching and an Integrative Approach from the users of the model [7], [8], [9]

Based on the problems described previously, the formulation of the research problem was formulated, namely (1) What is the need for a Multidisciplinary such as percentage and mean. The results of this survey were further explored by using interviews and generating qualitative data.

The population of this study were students of the PGSD Department of FIP Unesa who, in the odd semester of 2021, was in semester five which consisted of 6 classes. In collecting survey data, random samples were taken in class groups, obtained in two classes. Random selection of class groups is carried out using a lottery technique based on the assumption that students' abilities of the 2019 PGSD Department are relatively the same based on the results of the same selection test, both from written tests (cognitive) and interviews (affective and psychomotor). The number of students in each class is 32 and 35 students.
Literacy lecture model with Team Teaching and an Integrative Approach in terms of the profile of PGSD student graduates?; (2) What is the need for a Multidisciplinary Literacy lecture model with Team Teaching and an Integrative Approach from the perspective of PGSD students' opinions?; and (3) What is the need for a Multidisciplinary Literacy lecture model with Team Teaching and an Integrative Approach from the point of view of PGSD lecturers?

Based on the formulation of the research problem, the objectives of this research were formulated, namely (1) explaining the need for a Multidisciplinary Literacy lecture model with Team Teaching and an Integrative Approach in terms of the profile of PGSD student graduates; (2) describe the need for a Multidisciplinary Literacy lecture model with Team Teaching and an Integrative Approach from the perspective of PGSD students' opinions, and (3) describe the analysis of constraints on the needs of the Multidisciplinary Literacy lecture model with Team Teaching and an Integrative Approach?

\section{RESEARCH METHODS}

This study also needs to review the theoretical concepts related to multidisciplinary literacy with team teaching and an integrative approach. In the needs analysis and analysis of the constraints of the Multidisciplinary Literacy lecture model with Team Teaching and an Integrative Approach, (1) a survey of the needs of the Multidisciplinary Literacy lecture model with Team Teaching and an Integrative approach in PGSD; (2) Interviews with students and lecturers at PGSD; (3) The analysis of constraints is reflected in the problems faced by lecturers in team teaching- shaped learning. The needs and constraints analysis survey data was collected using questionnaires and interview guidelines. The data analysis technique used to process the needs and constraint analysis data in a questionnaire (quantitative data) was analyzed with simple statistics

This research data consists of quantitative and qualitative data. To obtain quantitative data from the questionnaire using a questionnaire instrument using a Likert scale of 1-4. The Likert scale used is a quantification which is interpreted as follows:

Table 1. Likert Scale

\begin{tabular}{|l|l|}
\hline Statement & Score Quantification \\
\hline Strongly Agree & 4 \\
\hline Agree & 3 \\
\hline Do not Agree & 2 \\
\hline Strongly Disagree & 1 \\
\hline
\end{tabular}

The qualitative data were obtained from interviews using interview guidelines. Quantitative data were 
analyzed using descriptive statistics. The qualitative

\section{RESEARCH RESULTS}

The research results on the needs analysis of the Multidisciplinary Literacy lecture model with Team Teaching and an integrative approach are described as follows. data were analyzed descriptively qualitatively.

3.1 The results of a survey of the need for a multidisciplinary literacy lecture model with team teaching and an integrative approach

Table 1. Student questionnaire data

\begin{tabular}{|c|c|c|c|c|c|c|c|c|c|c|}
\hline \multirow{2}{*}{ No } & \multirow{2}{*}{ Aspect } & \multirow{2}{*}{$\begin{array}{l}\text { Number of } \\
\text { Students }\end{array}$} & \multicolumn{2}{|c|}{ Answer 1} & \multicolumn{2}{|c|}{ Answer 2} & \multicolumn{2}{|c|}{ Answer 3} & \multicolumn{2}{|c|}{ Answer 4} \\
\hline & & & Amount & $\%$ & Amount & $\%$ & Amount & $\%$ & Amount & $\%$ \\
\hline 1 & $\begin{array}{l}\text { Multidiscipline literacy is the } \\
\text { literacy that is understood from } \\
\text { various disciplines that are } \\
\text { presented in one activity } \\
\text { sequentially }\end{array}$ & 67 & 0 & 0 & 0 & 0 & 5 & 7.5 & 62 & 92.5 \\
\hline 2 & $\begin{array}{l}\text { Multidisciplinary literacy in } \\
\text { higher education is by the } \\
\text { thematic approach to learning in } \\
\text { elementary school }\end{array}$ & 67 & 0 & 0 & 0 & 0 & 22 & 32.8 & 45 & 67.2 \\
\hline 3 & $\begin{array}{l}\text { Multidisciplinary Literacy } \\
\text { Lectures are essential to be } \\
\text { programmed at PGSD }\end{array}$ & 67 & 0 & 0 & 0 & 0 & 3 & 4.5 & 64 & 95.5 \\
\hline 4 & $\begin{array}{l}\text { Multidisciplinary Literacy lecture } \\
\text { model needs to be } \\
\text { developed in PGSD }\end{array}$ & 67 & 0 & 0 & 0 & 0 & 10 & 14.9 & 57 & 85.1 \\
\hline 5 & $\begin{array}{l}\text { Multidisciplinary Literacy } \\
\text { Lectures need to be carried out } \\
\text { in Team Teaching consisting of } \\
\text { several lecturers who have } \\
\text { different expertise (in science, } \\
\text { mathematics, Indonesian } \\
\text { language, social studies, and } \\
\text { civics education) }\end{array}$ & 67 & 0 & 0 & 0 & 0 & 21 & 31.3 & 42 & 62.7 \\
\hline 6 & $\begin{array}{l}\text { Multidisciplinary Literacy lecture } \\
\text { model with Team Teaching needs } \\
\text { to be designed regarding the } \\
\text { Integrative approach }\end{array}$ & 67 & 0 & 0 & 0 & 0 & 16 & 23.8 & 51 & 76.2 \\
\hline 7 & $\begin{array}{l}\text { It is necessary to make a } \\
\text { Multidisciplinary Literacy Lecture } \\
\text { Tool in Team Teaching with an } \\
\text { Integrative Approach in PGSD }\end{array}$ & 67 & 0 & 0 & 0 & 0 & 2 & 3 & 65 & 97 \\
\hline 8 & $\begin{array}{l}\text { It is necessary to make teaching } \\
\text { materials for Multidisciplinary } \\
\text { Literacy lectures with Team } \\
\text { Teaching and an integrative } \\
\text { approach that can be } \\
\text { implemented in PGSD }\end{array}$ & 67 & 0 & 0 & 0 & 0 & 1 & 1.5 & 66 & 98.5 \\
\hline
\end{tabular}




\begin{tabular}{|c|c|c|c|c|c|c|c|c|c|c|}
\hline 9 & $\begin{array}{l}\text { It is necessary to make media } \\
\text { for Multidisciplinary Literacy } \\
\text { lectures with Team Teaching } \\
\text { and an integrative approach } \\
\text { that can be implemented in } \\
\text { PGSD }\end{array}$ & 67 & 0 & 0 & 0 & 0 & 0 & 0 & 67 & 100 \\
\hline 10 & $\begin{array}{l}\text { It is necessary to make an } \\
\text { assessment system for } \\
\text { Multidisciplinary Literacy lectures } \\
\text { with Team Teaching and an } \\
\text { integrative approach that can be } \\
\text { implemented in PGSD }\end{array}$ & 67 & 0 & 0 & 0 & 0 & 0 & 7 & 60 & 89.5 \\
\hline
\end{tabular}

Table 2. Lecturer questionnaire data

\begin{tabular}{|c|c|c|c|c|c|c|c|c|c|c|}
\hline \multirow{2}{*}{ No } & \multirow{2}{*}{ Aspect } & \multirow{2}{*}{$\begin{array}{l}\text { Number of } \\
\text { Students }\end{array}$} & \multicolumn{2}{|c|}{ Answer 1} & \multicolumn{2}{|c|}{ Answer 2} & \multicolumn{2}{|c|}{ Answer 3} & \multicolumn{2}{|c|}{ Answer 4} \\
\hline & & & Amount & $\%$ & Amount & $\%$ & Amount & $\%$ & Amount & $\%$ \\
\hline 1 & $\begin{array}{l}\text { Multidiscipline literacy is the } \\
\text { literacy that is understood from } \\
\text { various disciplines that are } \\
\text { presented in one activity } \\
\text { sequentially }\end{array}$ & 3 & 0 & 0 & 0 & 0 & 1 & 33.3 & 2 & 66.7 \\
\hline 2 & $\begin{array}{l}\text { Multidisciplinary literacy in } \\
\text { higher education is by the } \\
\text { thematic approach to learning in } \\
\text { elementary school }\end{array}$ & 3 & 0 & 0 & 0 & 0 & 1 & 33.3 & 2 & 66.7 \\
\hline 3 & $\begin{array}{l}\text { Multidisciplinary Literacy } \\
\text { Lectures are important to be } \\
\text { programmed at PGSD }\end{array}$ & 3 & 0 & 0 & 0 & 0 & 0 & 0 & 3 & 100 \\
\hline 4 & $\begin{array}{l}\text { Multidisciplinary Literacy lecture } \\
\text { model needs to be } \\
\text { developed in PGSD }\end{array}$ & 3 & 0 & 0 & 0 & 0 & 0 & 0 & 3 & 100 \\
\hline 5 & $\begin{array}{l}\text { Multidisciplinary Literacy } \\
\text { Lectures need to be carried out } \\
\text { in Team Teaching consisting of } \\
\text { several lecturers who have } \\
\text { different expertise (in science, } \\
\text { mathematics, Indonesian } \\
\text { language, social studies, and } \\
\text { civic education) }\end{array}$ & 3 & 0 & 0 & 0 & 0 & 1 & 33.3 & 2 & 66.7 \\
\hline 6 & $\begin{array}{l}\text { Multidisciplinary Literacy lecture } \\
\text { model with Team Teaching } \\
\text { needs to be designed regarding } \\
\text { the Integrative approach }\end{array}$ & 3 & 0 & 0 & 0 & 0 & 1 & 33.3 & 2 & 67.7 \\
\hline 7 & $\begin{array}{l}\text { It is necessary to make a } \\
\text { Multidisciplinary Literacy Lecture } \\
\text { Tool in Team Teaching with an } \\
\text { Integrative Approach in PGSD }\end{array}$ & 3 & 0 & 0 & 0 & 0 & 0 & 0 & 3 & 100 \\
\hline 8 & $\begin{array}{l}\text { It is necessary to make teaching } \\
\text { materials for Multidisciplinary } \\
\text { Literacy lectures with Team }\end{array}$ & 3 & 0 & 0 & 0 & 0 & 0 & 0 & 3 & 100 \\
\hline
\end{tabular}




\begin{tabular}{|c|l|l|l|l|l|l|l|l|}
\hline 9 & $\begin{array}{l}\text { Teaching and an integrative } \\
\text { approach that can be } \\
\text { implemented in PGSD }\end{array}$ & & & & & & & \\
\hline $\begin{array}{l}\text { It is necessary to make media } \\
\text { for Multidisciplinary Literacy } \\
\text { lectures with Team Teaching } \\
\text { and an integrative approach } \\
\text { that can be implemented in } \\
\text { PGSD }\end{array}$ & 3 & 0 & 0 & 0 & 0 & 0 & 0 & 3 \\
\hline 10 & $\begin{array}{l}\text { It is necessary to make an } \\
\text { assessment system for } \\
\text { Multidisciplinary Literacy lectures } \\
\text { with Team Teaching and an } \\
\text { integrative approach that can be } \\
\text { implemented in PGSD }\end{array}$ & 3 & 0 & 0 & 0 & 0 & 0 & 0 \\
\hline
\end{tabular}

1) The data obtained through questionnaires were then dug deeper through interviews. From interviews with PGSD students and PGSD lecturers, the following data were obtained.

2) Multidisciplinary literacy lectures with team teaching and an integrative approach are important to be included in the pgsd curriculum because it provides students with in-depth understanding. After all, they are guided by a team of lecturers who have different and complementary areas of expertise.

3) Each lecturer has special expertise that can be combined in multidisciplinary literacy lectures with team teaching, and this integrative approach can be combined to design innovative thematic learning in elementary schools.

4) Multidisciplinary literacy lectures with team teaching and an integrative approach produce a comprehensive understanding for students because it is presented as a complete presentation material that is viewed from various scientific fields and has fulfilled the material elements and characteristics of the scientific fields involved.

5) In order for students to better understand the application of the thematic approach in elementary schools, the design of multidisciplinary literacy lectures with team teaching and an integrative approach can be a model for thematic learning in elementary schools

6) Multidisciplinary literacy lectures with team teaching and an integrative approach provide students with knowledge and experience to design comprehensive and non-overlapping learning so that they are more efficient and effective.

\section{CONCLUSIONS}

From the results of this study, the following conclusions can be conveyed:

1) The Multidisciplinary Literacy lecture model with Team Teaching and an Integrative Approach in terms of the profile of PGSD student graduates is needed because it provides a comprehensive understanding of students because lecturers teach them in different fields of expertise who work together during lectures;

2) The Multidisciplinary Literacy Lecture model with Team Teaching and an Integrative Approach from the perspective of PGSD students' opinions is needed so that students can have a thematic learning model in SD which consists of several subjects and is united in a theme; and

3) The Multidisciplinary Literacy lecture model with Team Teaching and an Integrative Approach from the perspective of the PGSD lecturers' opinion are important to design because the lecturers will provide material and assist students in designing thematic learning for SD, which combines several subjects that are united in a theme.

\section{ACKNOWLEDGMENTS}

The authors wish thanks to DRPM funding for support this research with Penelitian Terapan Unggulan Perguruan Tinggi Program 2021 with with number contract B/12122/UN38.9/LK.04.00/2021, Maret 18 2021. 


\section{REFERENCES}

[1] R. Fogarty, "Ten ways to integrate curriculum." Educational leadership 49, no. 2 (1991): 61-65.

[2] W. Sukartiningsih, "Pendidikan Karakter melalui Pembudayaan Bahasa yang Berkarakter Positif di Sekolah,” Jurnal Pendidikan Dasar: Jurnal Kajian Teori dan Hasil Penelitian., vol. 01, no. 1, pp. 6073,2012

[3] J. C.-Y. Sun and A. Y.-Z. Chen, "Effects of integrating dynamic concept maps with Interactive Response System on elementary school students' motivation and learning outcome: The case of antiphishing education," Computers \& Education, vol. 102, pp. 117-127, 2016, DOI: 10.1016/j.compedu.2016.08.002.

[4] A. Friedman, "To 'read' and 'write' pictures in early childhood: multimodal visual literacy through Israeli children's digital photography," Journal of Children and Media, vol. 12, no. 3, 2018, DOI: 10.1080/17482798.2018.1443147.

[5] M. Wilson, K. Scalise, and P. Gochyyev, "Rethinking ICT literacy: From computer skills to social network settings," Thinking Skills and Creativity, vol. 18, pp. 65-80, 2015, DOI: 10.1016/j.tsc.2015.05.001.

[6] C. Lai, Q. Wang, and J. Lei, "What factors predict undergraduate students' use of technology for learning? A case from Hong Kong," Computers \& Education, vol. 59, no. 2, pp. 569-579, 2012, DOI: 10.1016/j.compedu.2012.03.006.

[7] S. J. Daniel, "Education and the COVID-19 pandemic," Prospects, vol. 49, no. 1-2, 2020, DOI: 10.1007/s11125-020-09464-3.

[8] S. Setiati and M. K. Azwar, "COVID-19 and Indonesia," Acta medica Indonesiana, vol. 52, no. $1,2020$.

[9] P. Sun, X. Lu, C. Xu, W. Sun, and B. Pan, "Understanding of COVID-19 based on current evidence," Journal of Medical Virology, vol. 92, no. 6. 2020. DOI: $10.1002 /$ jmv. 25722 . 